Record of

\section{oceanographic achievement}

A Voyage of Discovery. (George Deacon 70th Anniversary Volume.) Supplement to Deep-Sea Research and Oceanographic Abstracts. Edited by Martin Angel. Pp. 696. (Pergamon: New York, 1977.) \$72; $£ 40$ (subscribers to Deep Sea Research, \$45; £25).

THIS volume forms a highly appropriate tribute to a remarkable man or, if Sir George Deacon would prefer it put in this way, then to a most remarkable record of achievement.

When, in 1972, we celebrated, most appropriately in Edinburgh, the centenary of the sailing of the Challenger, stock was naturally taken of British achievements in oceanography since that date. Then and for years afterwards Great Britain was the centre of deep-sea research, the high peak being represented by the completed publication of the Challenger Reports. But by that date an all-important influence had been lost.

As Margaret Deacon tells us in the initial contribution, the interest of the Admiralty in oceanographic research in 1880 and 1882 was under the direction of Staff-Commander Thomas Henry Tizard who had been navigating officer on the Challenger. After requests by Wyville Thomson, further observations were made in the FaeroeShetland Channel in the hope of determining the reasons for the striking differences in deep-sea temperatures observed there by himself and W. B. Carpenter during pre-Challenger expeditions in the Lightning and the Porcupine. An initial voyage in the shockingly unsuitable Knight Errant in 1880 was followed two years later by another on the Triton. On the basis of earlier published correspondence between Thomson and Tizard and of information contained in Tizard's journals in the possession of the National Maritime Muscum, we learn how and with what difficulties in the worst of weathers (though this was in the months of July and May) the existence of the predicted Wyville Thomson ridge was fully established in 1882.

By that time the mantle of Wyville Thomson had fallen on the broad shoulders of John Murray but his hopes of continuing deep-sea investigations, which depended on continuance of the Admiralty cooperation maintained over the previous 14 years, were to be disappointed. To quote Margaret Deacon's final words, "This field, however, was to remain almost completely closed to British scientists until the

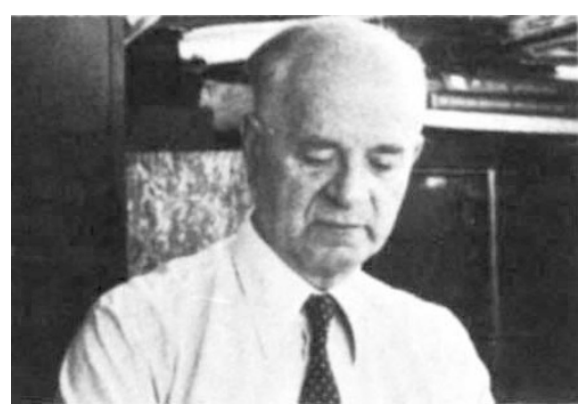

establishment of the Discovery investigations 10 years after Murray's death".

This brings us up to modern times, as it appears to one who then unsuccessfully sought appointment. What the Admiralty had previously neglected now became possible because of the surplus of money received for the use of the whaling station at South Georgia (this was before the advent of factory ships rendered shore facilities unnecessary). These investigations, under the initial direction of Stanley Kemp, were of immense significance both in their own right and in their effect on the development of oceanography in Great Britain. George Deacon participated in the second commission in R.S.S. William Scoresby in 1927-28 and in three of the first four commissions of R.R.S. Discovery II in 1929-30, 193133 and again in 1935-37 when he was principal scientist. It was in these years that Deacon provided the essential background to any understanding of the biology of whales, when he laid the foundations of modern knowledge about the water masses and water movements in the Southern Ocean.

During this period-again to iniroduce a personal note-those of us who served on the Fisheries Committee of the Development Commission (which one then hoped might evolve into a Fisheries Research Council) became increasingly concerned about the

\section{Metal-ligand equilibria}

Atlas of Metal-Ligand Equilibria in Aqueous Solution. By J. Kragten. Pp. 781. (Wiley: New York and London, 1978.) $£ 35$.

THE study of metal-ligand equilibria has often been assisted, following Ringbom, by the use of the parameter $M^{\prime}$ (the total concentration of metal ion not involved in the main reaction), the side-reaction coefficient (alpha, equal to $M^{\prime} /\left(\right.$ free $M^{n+}$ ), and conditional constants. For those familiar with these concepts, this atlas provides in convenient graphical form the results of computer calculations for 45 commonly-used metals in the presence of 29 common ligands. These can be used for a variety of problems in aqueous uneven balance of British marine research, so disproportionately strong on the biological side. Something in the nature of an institute of physical oceanography was clearly needed. In an unpredictable manner this was to emerge from the War-time activities of George Deacon at the Admiralty Research Laboratory. In 1949 the staff of that laboratory united with the biologists from the Discovery investigations to form the National Institute of Oceanography, later, under the umbrella of the Natural Environment Research Council, to become the Institute of Occanographic Sciences. In this way the scientific interests of the Admiralty became re-associated with the main stream of oceanographic research.

Little space is left to write about the contents of this impressive tribute, which begins with a list of Sir George Deacon's papers followed by 39 contributions from an even greater number of writers (as many have joint authorship). About half of these come from former colleagues at the Institute, the remainder from almost every leading centre of occanographic research in the world. Their subject matter is no less diverse, a consequence of the immense range of modern oceanographic research. Articles dealing with the water characteristics of the Southern Ocean and much else conccrning Antarctic water are followed by others covering many aspects of physical oceanography and then by contributions on biological subjects. The volume concludes, as appropriately as it begins, with reference to the whaling interests which have been of such momentous consequence in the development of British decp-sea research.

C. M. Yonge

Sir Maurice Yonge is Honorary Research Fellow in Zoology at the University of Edinburgh, UK.

solution chemistry and particularly for the prediction of hydroxide precipitation and in the planning of analytical procedures.

The expert will query some of the entries, a number of the omissions (for example, the ligands iodide and NTA), and the choice of some of the stability constants. As the jacket suggests the graphs could also be of considerable value to a much wider readership but unfortunately the introduction, which sets out to explain the value of the graphs, is not clearly written and will not be easily understood by the non-expert. As a result, one feels that many who could profit from this compilation will fail to refer to it.

C. S. G. Phillips

C. S. G. Phillips is Lecturer in Inorganic Chemistry at the University of Oxford, UK. 